\title{
EFFECT OF L-CARNITINE ADMINISTRATION ON SERUM INSULIN AND ADIPONECTIN LEVELS, AND AMPK, APPL1 AND PPAR $\gamma$ GENE EXPRESSION IN STZ-INDUCED DIABETIC RAT LIVER
}

\author{
B. SHAHOUZEHI $I^{1}$ K. BARKHORDARI ${ }^{2}$, S. AMINIZADEH $H^{3}$, Y. MASOUMI-ARDAKANI ${ }^{*}$ \\ ${ }^{1}$ Cardiovascular Research Center, Institute of Basic and Clinical Physiology \\ Sciences, Kerman University of Medical Sciences, Kerman, Iran; \\ e-mail: bshahouzehi@yahoo.com; \\ ${ }^{2}$ Department of Virology, Afzalipour School of Medicine, \\ Kerman University of Medical Sciences, Kerman, Iran; \\ e-mail: khabatzanbil@gmail.com; \\ ${ }^{3}$ Physiology Research Center, Institute of Basic and Clinical Physiology \\ Sciences, Kerman University of Medical Sciences, Kerman, Iran; \\ e-mail: soheilaminizadeh@gmail.com; \\ ${ }^{4}$ Physiology Research Center, Institute of Basic and Clinical Physiology \\ Sciences, Kerman University of Medical Sciences, Kerman, Iran; \\ *e-mail:ymab125@yahoo.com
}

Diabetes is considered as a metabolic disease in which insulin secretion and functions are disturbed and characterized by hyperglycemia. L-carnitine is synthesized in most mammals and plays critical role in fatty acid oxidation and energy production. Data about the L-carnitine hypoglycemic effects are controversial. We evaluated long-term oral L-carnitine administration effects on blood glucose, insulin and adiponectin levels, as well as expression of AMPK, APPL1 and PPAR genes in liver of STZ-induced diabetic rats. Group 1 (control), did not receive any treatment, group 2 received $50 \mathrm{mg} / \mathrm{kg} S T Z$ by i.p injection, group 3 received single dose of $50 \mathrm{mg} / \mathrm{kg} \mathrm{STZ} \mathrm{by} \mathrm{i.p} \mathrm{injection} \mathrm{and} \mathrm{also} 600 \mathrm{mg} / \mathrm{kg} /$ day L-carnitine orally for 5 weeks. Our results showed that L-carnitine long-term oral supplementation significantly reduced blood glucose and normalized insulin levels in diabetic rats. Also, we found that L-carnitine significantly increased AMPK and APPL1 expression, and showed a mild elevation of PPARy expression. In sum, we suggest that long-term Lcarnitine supplementation has beneficial effects on diabetic rats which showed hypoglycemic effects. Probably the beneficial effects of L-carnitine are contributed to the upregulation of insulin sensitizers such as AMPK and adiponectin.

Key words: L-carnitine, STZ-induced diabetes, adiponectin, AMPK, APPL1, PPAR .

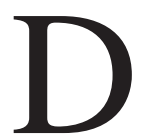
iabetes is a worldwide chronic disorder which considered as one of the most prevalent metabolic complication. It is characterized by remarkable elevation of blood glucose levels and disturbed lipid homeostasis [1, 2]. In 2013, about 382 million individual burden diabetes and it has been estimated that this number will increase and reach about 592 million by 2035 [2].

L-carnitine ( $\beta$-hydroxy- $\gamma$-N-trimethyl ammonium butyrate) is a non-nutrient supplement that is synthesized from essential amino acids, lysine and methionine, in liver, brain and kidney of most mammals [3, 4]. L-carnitine facilitates long-chain fatty acids transportation into the mitochondria as acylcarnitine and helps fatty acids to entered betaoxidation pathway. In mitochondria, these fatty acids were oxidized and produced coenzyme A (CoA). These obtained CoA entered to tricarboxylic acid (TCA) cycle and generate energy in the mitochondrial respiratory chain. Therefore, L-carnitine has an important role in fatty acids energy release and is very important for lipid metabolism [5].

(C) 2017 Shahouzehi B. et al. This is an open-access article distributed under the terms of the Creative Commons Attribution License, which permits unrestricted use, distribution, and reproduction in any medium, provided the original author and source are credited. 
Following L-carnitine supplementation, fat utilization was promoted and TG levels were decreased [6]. It was reported that diabetic rats have reduced serum L-carnitine levels [7]. Cha Y. S. reviewed L-carnitine metabolic actions and has reported that L-carnitine affects obesity and blood glucose, but results obtained from other studies were controversial and L-carnitine some effects remained uncertain [8]. Hadadinezhad S. and colleagues showed that L-carnitine attenuated fasting blood glucose but there was no effect on hemoglobin $\mathrm{A}_{1 \mathrm{C}}$ and C-peptide in patients with diabetes mellitus [9]. Also, it has been reported that high dose of L-carnitine reduced diabetes severity and also improved cardiac function [10]. Xia Y. et al. showed that oral administration of $\mathrm{L}$-carnitine to mice was increased $\beta$-oxidation of fatty acids and also in liver maintained mitochondrial function [11].

Adiponectin promotes liver AMPK (AMP-activated protein kinase) activity and results in fatty acid $\beta$-oxidation and promotes glucose uptake. Finally, these metabolic changes result in the promotion of insulin sensitivity [12]. Anti-diabetic drugs, thiazolidinediones (TZDs), activate peroxisome proliferator-activated receptor-gamma (PPAR $\gamma$ ) and consequently increase insulin sensitivity. PPAR $\gamma$ activation promotes insulin sensitivity and improves insulin receptor signaling in diabetes [13, 14]. TZDs may affect insulin sensitivity by AMPK activation [12].

According to previous studies, L-carnitine showed valuable effects in diabetes and it has been reported that reduced glucose and lipid levels. But data about hypoglycemic effects of L-carnitine in diabetes are inconsistent $[1,10,15,16]$ and the mechanism of L-carnitine beneficial effects are not fully understood, therefore, we designed this study to evaluate oral L-carnitine supplementation effects on adiponectin and insulin circulating levels and also, expression of AMPK, PPAR $\gamma$ and APPL1 (adaptor protein containing pleckstrin homology domain, phosphotyrosine binding (PTB) domain and leucine zipper motif) genes in liver of STZ-induced diabetic rats.

\section{Materials and Methods}

Materials. Streptozotocin (STZ, S0130) and Lcarnitine (C0283) were purchased from Sigma. Adiponectin (KRP0041) and insulin (ERINS) measured by specific ELISA kits.

Preparation of reagents. STZ prepared in citrate buffer $(0.1 \mathrm{~N}, \mathrm{pH} 4.5)$ and introduced to animals by a single i.p injection and L-carnitine was prepared in phosphate buffer ( $\mathrm{pH}$ 7.4) and administrated orally to diabetic rats.

Methods. All animal procedures were conducted in accordance with the requirements of European Convention for the protection of Vertebrate Animals Used for Experimental and Other Scientific Purposes (Strasbourg, 1986). Twenty four male Wistar rats (190-210 g weight and 75-95 days of age) were randomly selected and after a week acclimatization were divided into three groups $(n=8)$. Group 1 control did not receive any treatment, group 2 received a single dose of STZ (50 mg/ $\mathrm{kg}$ ) by i.p injection to induce diabetes, group 3 received a single dose of STZ (50 mg/kg) by i.p injection and also $600 \mathrm{mg} / \mathrm{kg} /$ day L-carnitine orally for 5 weeks. Before beginning the L-carnitine treatment we make sure that the animals in groups 2 and 3 were diabetic, for this reason, $72 \mathrm{~h}$ after STZ injection the blood glucose was measured and animals that showed blood glucose more than $250 \mathrm{mg} / \mathrm{dl}$ after $12 \mathrm{~h}$ fasting were entered to the study. At the end of the study (after 35 days) and after $12 \mathrm{~h}$ fasting overnight, animals were anesthetized with ether and sacrificed, the blood samples were collected and maintained $1 \mathrm{~h}$ at room temperature and centrifuged and then serum was collected to measure the glucose, adiponectin, and insulin levels. Also, the liver tissues were dissected and washed with cold saline and immediately frozen by liquid nitrogen and kept in $-80^{\circ} \mathrm{C}[8,15]$.

Determination of serum adiponectin and insulin levels. Specific ELISA kits were used to assay adiponectin and insulin in serum. All measurements were according to the manufacturer's protocol.

Semi-quantitative RT-PCR. About $75 \mathrm{mg}$ of liver tissue was removed from storage for total RNA extraction. Liver tissue homogenization was performed by Ultrasonic Processor (Hielscher, UP200H). Total RNA was extracted by guanidine isothiocyanate-phenol-chloroform method (RNX plus reagent). For cDNA synthesis, 500 nanograms of total RNA was used by M-MuLV reverse transcriptase and oligo-dT primers. PCR was performed in Bio-Rad MJ Mini Personal thermal cycler. PCR reaction contained 200 nanograms of cDNA, $50 \mathrm{pM}$ of target gene forward and reverse primers, $10 \mathrm{ul}$ PCR master mix, the final volume was $20 \mu \mathrm{l}$. Each gene's expression performed duplicate. The PCR cycles were as follow; $95^{\circ} \mathrm{C}$ for $10 \mathrm{~min}$, then 30 cycles of $94^{\circ} \mathrm{C}$ for $45 \mathrm{~s}, 60^{\circ} \mathrm{C}$ for $1 \mathrm{~min}$, and $45 \mathrm{~s}$ at $72^{\circ} \mathrm{C}$, and $5 \mathrm{~min}$ final extension at $72{ }^{\circ} \mathrm{C}$. For analysis of the PCR products, we performed agarose gel elec- 
Table 1. Sequences of RT-PCR primers

\begin{tabular}{l|l|l|c}
\hline \multicolumn{1}{c|}{ Transcript } & \multicolumn{1}{c|}{ Forward primer $\left(5^{\prime}-3^{\prime}\right)$} & \multicolumn{1}{c}{ Reverse primer $\left(5^{\prime}-3^{\prime}\right)$} & $\begin{array}{c}\text { Product } \\
\text { Base pair }\end{array}$ \\
\hline AMPK & AGAGAACGTGTTGCTGGACG & TGGAGGCGAGGTAGAACTCA & 608 \\
APPL1 & TTTCTTAGGAAGGGGCTGCG & TGGCATCAGCGAGTTGAGTT & 450 \\
PPAR $\gamma$ & TGATGCACTGCCTATGAGCAC & TGAGACATCCCCACAGCAAG & 561 \\
GAPDH & ACCACAAGTCCATGCCATCAC & TCCACCACCCTGTTGCTGTA & 452 \\
\hline
\end{tabular}

trophoresis on $2 \%$ agarose gel $(100 \mathrm{v}, 45 \mathrm{~min})$, then by using gel documentation instrument. Primers (Table 1) were purchased from Sinagen (Sinagen Inc., Tehran, Iran). Bands were visualized and were quantified by using Image J software [17].

Statistical analysis. Statistical analyses were performed by SPSS 19 software (SPSS Inc., Chicago, USA). The data are expressed as mean \pm SEM. For comparison between groups, we used one-way analysis of variance (ANOVA) followed by the Tukey's post hoc test.

\section{Results and Discussion}

Our results showed that long-term L-carnitine supplementation reduces blood glucose significantly. Also, L-carnitine leads to significant elevation of adiponectin levels in diabetic rats, there was a mild but significant elevation of insulin after Lcarnitine administration. Body weight was significantly reduced in the diabetic control group and the diabetic group which received L-carnitine compared to control group (Table 2). Also, L-carnitine showed remarkable effects on $A M P K, A P P L 1$ and PPAR $\gamma$ gene expression, and up regulated these genes compared to diabetic group (Figure, $A-C$ ).

Diabetes is one of the most prevalent metabolic diseases which affect many people worldwide [1]. L-carnitine is an endogenous vitamin-like compound which synthesized by most mammals and is very important for glucose and lipid homeostasis. It was reported that L-carnitine levels were remarkably reduced in diabetes models $[1,10,15,18]$. It was also demonstrated that L-carnitine in serum and cardiac tissue of diabetic animal were reduced [19]. But data about L-carnitine hypoglycemic effects are controversial. Abdel-Razek H. reported that s.c. administration of L-carnitine improved glucose utilization in diabetic rats [1]. It demonstrated that long term L-carnitine supplementation reduced TG and cholesterol but hyperglycemia was still present in diabetic rats [15]. On the other hand, Bazotte R. B. and Lopes-Bertolini G. showed that L-carnitine administration showed no significant effects on blood glucose and total cholesterol but normalized blood TG levels in diabetic rats [16]. Rodrigues B. and colleagues were suggested that high dose of L-carnitine reduced diabetes severity and also improved cardiac function [10]. We showed that long-term supplementation of L-carnitine $(600 \mathrm{mg} /$ $\mathrm{kg}$ /day, orally) after five weeks, significantly improved some parameters in STZ-induced diabetic rats. We found that L-carnitine attenuated blood glucose levels compared to the diabetic non-treated group which are in contrast with Patel J. et al. and Bazotte R. B. and Lopes-Bertolini G. studies.

Ta ble 2. Body weight, glucose, insulin and adiponectin levels and L-carnitine supplementation effects on these parameters in diabetic rats

\begin{tabular}{|c|c|c|c|c|c|}
\hline \multirow{2}{*}{ Groups } & \multicolumn{2}{|c|}{ Body weight, g } & \multirow{2}{*}{ Glucose, mg/dl } & \multirow{2}{*}{ Insulin, mIU/l } & \multirow{2}{*}{$\begin{array}{l}\text { Adiponectin, } \\
\text { ug } / \mathrm{ml}\end{array}$} \\
\hline & day zero & day 35 & & & \\
\hline Control & $201.8 \pm 7.1$ & $221.5 \pm 7.0$ & $89.2 \pm 3.1$ & $12.4 \pm 0.82$ & $9.82 \pm 0.31$ \\
\hline Diabetes & $205.4 \pm 7.0$ & $171.4 \pm 11.0 *$ & $277 \pm 11^{*}$ & $3.34 \pm 0.41^{*}$ & $4.55 \pm 0.35^{*}$ \\
\hline $\begin{array}{l}\text { Diabetes + } \\
\text { L-Carnitine }\end{array}$ & $203.0 \pm 7.7$ & $188.3 \pm 11.2^{*}$ & $170.0 \pm 8.9^{*, \#}$ & $6.6 \pm 0.61^{*, \#}$ & $9.11 \pm 0.44^{\#}$ \\
\hline
\end{tabular}

The data are expressed as mean \pm sem. *Statistically significant compared to control group, \# statistically significant compared to Diabetes control group $(n=8)$ 
A
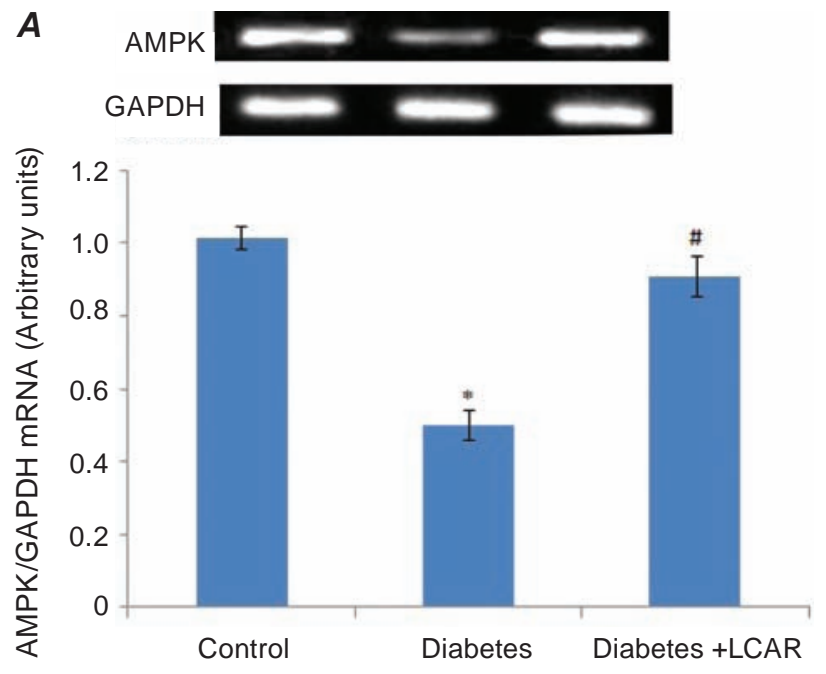

B
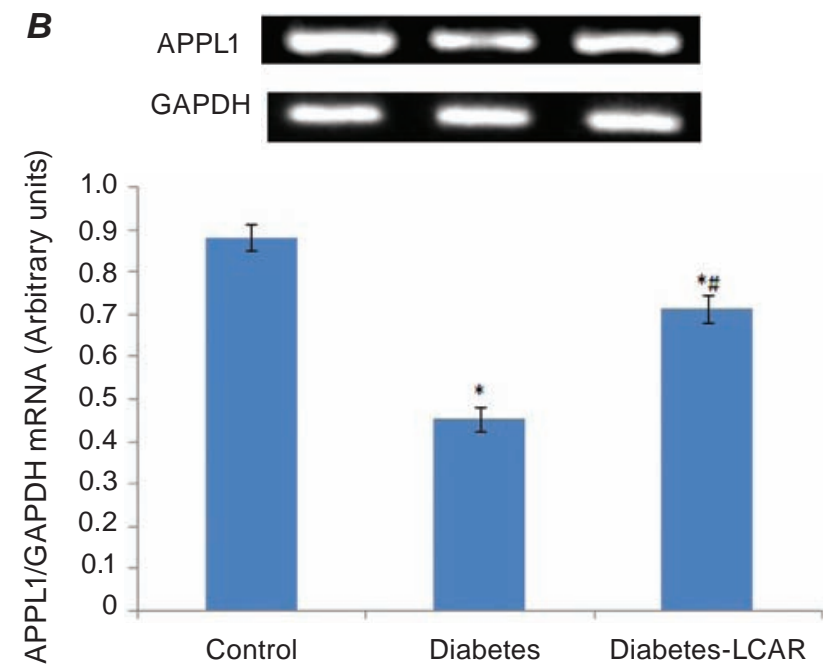
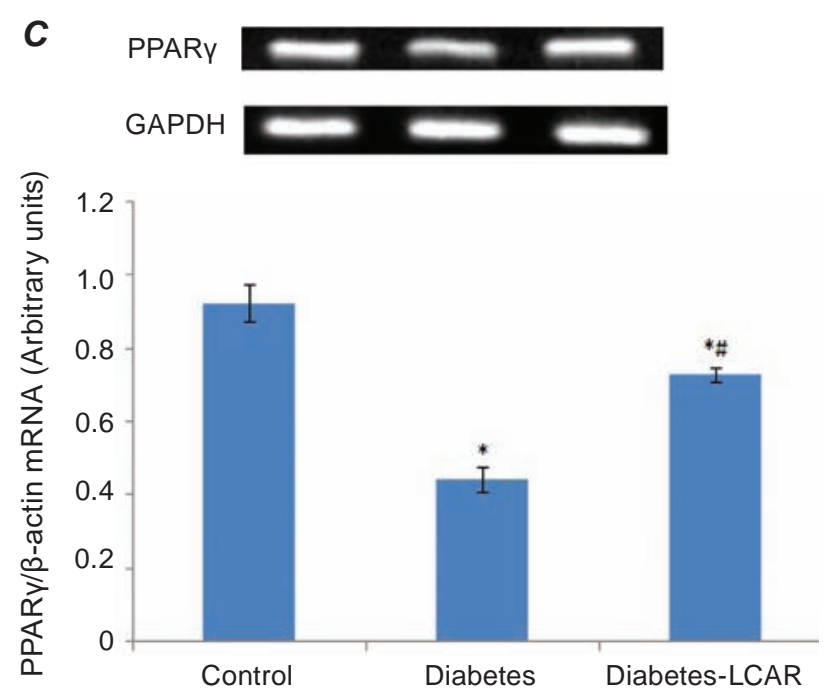

Expression of AMPK (A), APPL1 (B) and PPARy (C) genes as evaluated by RT-PCR. Data are expressed as mean \pm SEM. * Statistically significant compared to the control group, \# statistically significant compared to the diabetes group. $P<0.05$ was considered as significant $(n=8)$

The previous study demonstrated that L-carnitine has remarkable anti-diabetic effects and it probably correlated to L-carnitine antioxidant activity [18]. In the diabetic animal model, $500 \mathrm{mg} / \mathrm{kg} \mathrm{L-}$ carnitine which was administrated by i.p injection for a month showed anti-oxidant activity [20]. Therefore, anti-diabetic and hypoglycemic effects of Lcarnitine could be partly related to its anti-oxidative effects.

Oral administration of L-carnitine increased beta-oxidation of fatty acids and also in liver maintained mitochondrial function. Long-chain acylcarnitine has detergent effects on mitochondria membrane. L-carnitine supplementation reduces the chance of long-chain acylcarnitine accumulation in mitochondria space and therefore, protects membrane against destruction. Diabetes is along with oxidative stress which affects antioxidative defense against ROS [11, 21]. Therefore, mitochondria protective effects of L-carnitine can be considered as Lcarnitine beneficial effects observed in STZ-induced diabetic rats.

Adiponectin levels were extensively studied in diabetes and other metabolic diseases. Adiponectin was decreased in diabetes, insulin resistance and atherosclerosis and also reduced adiponectin levels related to diabetes and other metabolic complications development. Also, it was reported that PPAR activators improved diabetes and this effect was adiponectin-dependent [22-24]. We found that L- 
carnitine long-term administration to diabetic rats improved diabetes and this was related to adiponectin levels in serum which significantly increased after L-carnitine supplementation. As beneficial effects of adiponectin over diabetes are well proved, therefore, elevated adiponectin levels compared to diabetes control group in our study could be considered as responsible for beneficial effects of long-term L-carnitine supplementation in diabetes.

$\operatorname{PPAR} \gamma$ activation in liver attenuates intracellular lipid contents, promotes insulin sensitivity, improve insulin receptor signaling in diabetes, increase insulin secretion and inhibit gluconeogenesis. Also, TZDs which are strong insulin sensitizers' drugs, act via PPAR $\gamma$ agonism $[13,14]$. Besides TZDs benficial effects in diabetes there are some deteriorating effects following TZDs administration which include hepatotoxicity and hepatic failure [25]. Our results showed that PPAR $\gamma$ gene expression elevated by L-carnitine supplementation in diabetic rats, therefore L-carnitine exerts insulin-sensitizing effects by upregulation of PPAR $\gamma$.

AMPK is an energy sensor which plays a pivotal role in energy homeostasis. AMPK responds to AMP:ATP ratio in cells. AMPK activates catabolic pathways such as fatty acids beta-oxidation, and inhibits synthetic pathways such as lipogenesis and gluconeogenesis in the liver [14]. Adiponectin exerts its function by binding to membrane receptors and following adiponectin binding to its receptor, the intracellular domain of receptors recruit APPL1 [26]. Deepa S. S. and Dong L. Q. showed that APPL1 is implicated in adiponectin signaling in the liver [27] and also, Mao X. and colleagues showed that adiponectin stimulates interaction of APPL1 with adiponectin receptors [28]. We showed that L-carnitine administration to diabetic rats increased APPL1 gene expression. It has been reported that L-carnitine supplementation in non-diabetic subjects increased adiponectin levels [29], here we found that L-carnitine oral administration was able to increase adiponectin levels in diabetic rats. Therefore, elevated adiponectin interacts with its receptor and recruits APPL1 which involved in downstream effects of adiponectin such as AMPK activation and insulin sensitizing effects.

Finally, we hypothesized that L-carnitine longterm supplementation to STZ-induced diabetic rats exerts hypoglycemic and possibly indirect insulinsensitizing effects. We assumed that these effects are mediated via serum adiponectin elevation which in turn elevated AMPK and PPAR $\gamma$ which net effects of these factors resulted in reduced blood glucose and increased insulin sensitivity. Therefore, L-carnitine supplementation can account for as a good therapeutic and hypoglycemic candidate in diabetic subjects.

Acknowledgement. This research was financially supported by Kerman University Research Council.

\section{ВПЛИВ L-КАРНІТИНУ НА РІВЕНЬ ІНСУЛІНУ І АДИПОНЕКТИНУ В СИРОВАТЦІ КРОВІ, А ТАКОЖ НА ЕКСПРЕСІЮ ГЕНІВ АМРК, APPL1 I PPAR $\gamma$ У ПЕЧІНЦI ЩУРІВ ЗІ СТРЕПТОЗОТОЦИН- ІНДУКОВАНИМ ДІАБЕТОМ}

B. Shahouzehi ${ }^{1}$, K. Barkhordari², S. Aminizadeh ${ }^{3}$, Y. Masoumi-Ardakani ${ }^{4}$

${ }^{1}$ Cardiovascular Research Center, Institute of Basic and Clinical Physiology Sciences, Kerman University of Medical Sciences, Kerman, Iran; e-mail: bshahouzehi@yahoo.com; ${ }^{2}$ Department of Virology, Afzalipour School of Medicine, Kerman University of Medical Sciences, Kerman, Iran; e-mail: khabatzanbil@gmail.com; ${ }^{3}$ Physiology Research Center, Institute of Basic and Clinical Physiology Sciences, Kerman

University of Medical Sciences, Kerman, Iran; e-mail: soheilaminizadeh@gmail.com;

${ }^{4}$ Physiology Research Center, Institute of Basic and Clinical Physiology Sciences, Kerman

University of Medical Sciences, Kerman, Iran; e-mail: ymab125@yahoo.com

Діабет - метаболічне захворювання, яке характеризується порушенням секреції та функції інсуліну i, як наслідок, розвитком гіперглікемії. L-Карнітин, що синтезується в організмі більшості ссавців, відіграє ключову роль в окисленні жирних кислот і $є$ джерелом енергії. Дані про гіпоглікемічний ефект L-карнітину суперечливі. У роботі вивчали довгостроковий ефект перорально введеного L-карнітину на рівень глюкози, інсуліну та адипонектину в крові, а також експресію генів AMPK, APPL1 і PPARy в печінці діабетичних щурів. Самців щурів (190-210 г) було випадковим чином розділено на три групи $(n=8)$. Тварини групи 1 (контроль) не отримували ніяких препаратів, у групі 2 в тварин діабет спричиню- 
вали введенням 50 мг/кг стрептозотоцину (в/ч ін'єкція), у групі 3 щурам вводили стретозотоцин (50 мг/кг, в/ч ін'єкція одноразово), а також L-карнітин (600 мг/кг/день перорально) протягом 5 тижнів. Виявлено, що тривале введення L-карнітину значно знижувало рівень глюкози в крові і нормалізувало рівень інсуліну в щурів iз діабетом. Вивчення експресії генів показало, що L-карнітин істотно збільшував експресію AMPK і APPL1 і незначною мірою підвищував експресію PPAR . Таким чином, показано, що тривале застосування L-карнітину цілюще впливає на діабетичних щурів, виявляючи сенсибілізуючу та гіпоглікемічну дію.

К л ю ч о в і с ло в а: L-карнітин, стрептозотоцин, діабет, адипонектин, AMPK, APPL1, PPAR .

\section{ВЛИЯНИЕ L-КАРНИТИНА НА У РОВЕНЬ ИНСУЛИНА И АДИПОНЕКТИНА В СЫВОРОТКЕ КРОВИ, А ТАКЖЕ НА ЭКСПРЕССИЮ ГЕНОВ AMPК, APPL1 И PРAR $\gamma$ В ПЕЧЕНИ КРЫС СО СТРЕПТОЗОТОЦИН- ИНДУЦИРОВАННЫМ ДИАБЕТОМ}

\section{B. Shahouzehi ${ }^{1}$, K. Barkhordari ${ }^{2}$,}

S. Aminizadeh ${ }^{3}$, Y. Masoumi-Ardakani ${ }^{4}$

${ }^{1}$ Cardiovascular Research Center, Institute of Basic and Clinical Physiology Sciences, Kerman University of Medical Sciences, Kerman, Iran; e-mail: bshahouzehi@yahoo.com; ${ }^{2}$ Department of Virology, Afzalipour School of Medicine, Kerman University of Medical Sciences, Kerman, Iran; e-mail: khabatzanbil@gmail.com;

${ }^{3}$ Physiology Research Center, Institute of Basic and Clinical Physiology Sciences, Kerman

University of Medical Sciences, Kerman, Iran; e-mail: soheilaminizadeh@gmail.com;

${ }^{4}$ Physiology Research Center, Institute of Basic and Clinical Physiology Sciences, Kerman

University of Medical Sciences, Kerman, Iran; e-mail: ymab125@yahoo.com

Диабет - метаболическое заболевание, которое характеризуется нарушением секреции и функции инсулина и, как следствие, развитием гипергликемии. Синтезирующийся в организме большинства млекопитающих L-карнитин, игра- ет ключевую роль в окислении жирных кислот и является источником энергии. Данные о гипогликемическом эффекте L-карнитина противоречивы. В работе изучали долгосрочный эффект перорально введенного L-карнитина на уровень глюкозы, инсулина и адипонектина в крови, а также экспрессию генов AMPK, APPL1 и PPAR в печени крыс со стрептозотоцининдуцированным диабетом. Самцы крыс (190-210 г) были случайным образом разделены на три группы $(n=8)$. Животные в группе 1 (контроль) не получали никаких препаратов, у животных группы 2 вызывали диабет введением 50 мг/кг стрептозотоцина (в/бр инъекция), в группе 3 крысам однократно вводили стретозотоцин (50 мг/кг, в/бр инъекция), а также L-карнитин (600 мг/кг/ день, перорально) в течение 5 недель. Обнаружено, что длительное введение L-карнитина значительно снижало уровень глюкозы в крови и нормализовало уровень инсулина у крыс с диабетом. Кроме того установлено, что L-карнитин существенно увеличивал экспрессию АMPK и APPL1 и незначительно повышал экспрессию $P P A R \gamma$. Таким образом, показано, что длительное применение L-карнитина благотворно влияет на крыс со стрептозотоцининдуцированным диабетом, проявляя сенсибилизирующее и гипогликемическое действие.

К л ю че в ы е с л о в а: L-карнитин, стрептозотоцин, диабет, адипонектин, AMPK, APPL1, PPAR .

\section{References}

1. Abdel-Razek HA. Beneficial effect of L-carnitine on the neuromuscular performance in diabetic rats. Menoufia Med J. 2010; 23: 159-173.

2. Guariguata L, Whiting DR, Hambleton I, Beagley J, Linnenkamp U, Shaw JE. Global estimates of diabetes prevalence for 2013 and projections for 2035. Diabetes Res Clin Pract. 2014; 103(2): 137-149.

3. Cave MC, Hurt RT, Frazier TH, Matheson PJ, Garrison RN, McClain CJ, McClave SA. Obesity, inflammation, and the potential application of pharmaconutrition. Nutr Clin Pract. 2008; 23(1): 16-34.

4. Leibovitz B, Mueller J. Carnitine. J Optimal Nutr. 1993; 2(2): 90-109.

5. Alipour B, Barzegar A, Panahi F, Safaeian A, Eshaghi M. Effect of L-carnitine supplemen- 
tation on metabolic status in obese diabetic women with hypocaloric diet. Health Scope. 2014; 3(1): e14615.

6. Ramsay RR. The carnitine acyltransferases: modulators of acyl-CoA-dependent reactions. Biochem Soc Trans. 2000; 28(2): 182-186.

7. Bin Aleem S, Hussain MM, Farooq Y. Serum levo-carnitine levels and skeletal muscle functions in type 2 diabetes mellitus in rodents. J Coll Physicians Surg Pak. 2013; 23(2): 132-136.

8. Cha YS. Effects of L-carnitine on obesity, diabetes, and as an ergogenic aid. Asia Pac $J$ Clin Nutr. 2008; 17 Suppl 1: 306-308.

9. Hadadinezhad S, Ghazaleh N, Razavi Z. Effects of L-Carnitine on Glycemic Control and C-Peptide Levels in Patients with Type 2 Diabetes Mellitus. Turk Jem. 2008; 12(1): 1-3.

10. Rodrigues B, Xiang H, McNeill JH. Effect of L-carnitine treatment on lipid metabolism and cardiac performance in chronically diabetic rats. Diabetes. 1988; 37(10): 1358-1364.

11. Xia Y, Li Q, Zhong W, Dong J, Wang Z, Wang C. L-carnitine ameliorated fatty liver in highcalorie diet/STZ-induced type 2 diabetic mice by improving mitochondrial function. Diabetol Metab Syndr. 2011; 3: 31.

12. Lim CT, Kola B, Korbonits M. AMPK as a mediator of hormonal signalling. $J \mathrm{Mol}$ Endocrinol. 2010; 44(2): 87-97.

13. Janani C, Ranjitha Kumari BD. PPAR gamma gene - a review. Diabetes Metab Syndr. 2015; 9(1): 46-50.

14. Lee WH, Kim SG. AMPK-Dependent Metabolic Regulation by PPAR Agonists. PPAR Res. 2010; 2010. pii: 549101.

15. Patel J, Goyal R, Bhatt P. Beneficial effects of levo-carnitine on lipid metabolism and cardiac function in neonatal streptozotocin rat model of diabetes. Int J Diabetes Metabolism. 2008; 16: 29-34.

16. Bazotte RB, Lopes-Bertolini G. Effects of oral L-carnitine and DL-carnitine supplementation on alloxan-diabetic rats. Braz Arch Biol Technol. 2012; 55(1): 81-88.

17. Najafipour H, Vakili A, Shahouzehi B, Soltani Hekmat A, Masoomi Y, Yeganeh Hajahmadi M, Esmaeli-Mahani S. Investigation of changes in apelin receptor mRNA and protein expression in the myocardium and aorta of rats with twokidney, one-clip (2K1C) Goldblatt hypertension. J Physiol Biochem. 2015; 71(2): 165-175.
18. Mansour HH. Effect of L-Carnitine on Endothelial Dysfunction markers in DiabeticIrradiated rats. Int J Toxicol Appl Pharmacol. 2013; 3(1): 1-9.

19. Malone JI, Schocken DD, Morrison AD, GilbertBarness E. Diabetic cardiomyopathy and carnitine deficiency. J Diabetes Complications. 1999; 13(2): 86-90.

20. Uysal N, Yalaz G, Acikgoz O, Gonenc S, Kayatekin BM. Effect of L-carnitine on diabetogenic action of streptozotocin in rats. Neuro Endocrinol Lett. 2005; 26(4):419-422.

21. Aoshima S, Fujisawa S, Kobayashi A. Changes in the subcellular distribution of free carnitine and its acyl derivatives in diabetic rat hearts following treatment with L-carnitine. Jpn Heart J. 1993; 34(6): 763-772.

22. Yamauchi T, Kadowaki T. Physiological and pathophysiological roles of adiponectin and adiponectin receptors in the integrated regulation of metabolic and cardiovascular diseases. Int $J$ Obes (Lond). 2008; 32 Suppl 7: S13-S18.

23. Shahouzehi B, Shokoohi M, Najafipour H. The effect of opium addiction on serum adiponectin and leptin levels in male subjects: a case control study from Kerman Coronary Artery Disease Risk Factors Study (KERCADRS). EXCLI $J$. 2013; 12: 916-923.

24. Yang B, Brown KK, Chen L, Carrick KM, Clifton LG, McNulty JA, Winegar DA, Strum JC, Stimpson SA, Pahel GL. Serum adiponectin as a biomarker for in vivo PPARgamma activation and PPARgamma agonist-induced efficacy on insulin sensitization/lipid lowering in rats. $B M C$ Pharmacol. 2004; 4: 23.

25. Rogue A, Spire C, Brun M, Claude N, Guillouzo A. Gene Expression Changes Induced by PPAR Gamma Agonists in Animal and Human Liver. PPAR Res. 2010; 2010: 325183.

26. Deepa SS, Zhou L, Ryu J, Wang C, Mao X, Li C, Zhang N, Musi N, DeFronzo RA, Liu F, Dong LQ. APPL1 mediates adiponectin-induced LKB1 cytosolic localization through the PP2APKCzeta signaling pathway. Mol Endocrinol. 2011; 25(10): 1773-1785.

27. Deepa SS, Dong LQ. APPL1: role in adiponectin signaling and beyond. Am J Physiol Endocrinol Metab. 2009; 296(1): E22-E36.

28. Mao X, Kikani CK, Riojas RA, Langlais P, Wang L, Ramos FJ, Fang Q, Christ-Roberts CY, Hong JY, Kim RY, Liu F, Dong LQ. APPL1 
binds to adiponectin receptors and mediates adiponectin signalling and function. Nat Cell Biol. 2006; 8(5): 516-523.

29. Odo S, Tanabe K, Yamauchi M. A pilot clinical trial on L-carnitine supplementation in combination with motivation training: effects on weight management in healthy volunteers. Food Nutr Sci. 2013; 4(2): 222-231.

Received 07.08.2017 